\title{
Biological aspects of Hypostomus affinis (Siluriformes: Loricariidae) in Brazilian coastal rivers
}

\author{
Aspectos biológicos do Hypostomus affinis (Siluriformes: Loricariidae) \\ em rios costeiros brasileiros
}

Tiago Magalhães da Silva Freitas ${ }^{1 *}$ (D), Gilberto Nepomuceno Salvador ${ }^{2}$ (D)

\begin{abstract}
${ }^{1}$ Faculdade de Ciências Naturais, Campus Universitário do Marajó-Breves, Universidade Federal do Pará, Alameda IV, 3418, Parque Universitário, CEP 68800-000, Breves, PA, Brasil

${ }^{2}$ Laboratório de Ecologia e Conservação, Instituto de Ciências Biológicas, Universidade Federal do Pará, Rua Augusto Corrêa, 01, Guamá, CEP 66075-110, Belém, PA, Brasil

*e-mail: freitastms@gmail.com
\end{abstract}

Cite as: Freitas, T.M.S. and Salvador, G.N. Biological aspects of Hypostomus affinis (Siluriformes: Loricariidae) in Brazilian coastal rivers. Acta Limnologica Brasiliensia, 2022, vol. 34, e3.

\begin{abstract}
Aim: Determine the length-weight relationship (LWR), the period of reproduction, and evaluate the variation of the condition factor $(\mathrm{K})$ of Hypostomus affinis from two coastal drainages in southeastern Brazil, assessing the influence of the rainfall on these biological aspects. Methods: fish were sampled quarterly between April 2008 and April 2010 in tributaries of the Doce River basin (DRB) and the Paraíba do Sul River basin (PSRB). Specimens were caught using gillnets. LWR parameters were assessed by location and sex through a t-test. We used the frequency of mature specimens $\left(\mathrm{F}_{\mathrm{M}}\right)$ to evaluate the breeding period. Both $\mathrm{F}_{\mathrm{M}}$ and $\mathrm{K}$ values were assessed by a sinusoidal equation. Results: $\mathrm{A}$ total of 492 specimens was captured, of which 128 were from the Doce River basin (DRB) and 364 from the Paraíba do Sul River basin (PSRB). In both areas, specimens showed a negative allometric growth type. We collected mature specimens along the studied period in both drainages, with the highest frequency observed at the beginning of the rainy season. We found a positive correlation between the rate of matures and the local rainfall variation. The condition factor $(\mathrm{K})$ was lower for specimens from DRB and did not show a cyclic trend. On the other hand, we observed a cyclic chance of the $\mathrm{K}$ values for the individual from the PSRB, peaking in the transitional dry-rainy period. However, it was not possible to correlate it to the rainfall variation. Conclusions: LWR parameters of $H$. affinis were consistent with data already available in the literature. The rainfall may influence the $\mathrm{F}_{\mathrm{M}}$ but not the $\mathrm{K}$ values. In this case, biological characteristics such as reproduction and (or) feeding may be jointly driving a discrete variation of $\mathrm{K}$ values. The reduction in $\mathrm{K}$ values in the rainy periods suggests a remarkable energetic cost for the reproductive process. In short, our results help us to understand the life cycle of a fish species within a highly modified environment, especially by dams.
\end{abstract}

Keywords: armored catfish; length-weight relationship; fish biology; reproduction; condition factor.

Resumo: Objetivo: Determinar a relação peso-comprimento (LWR), período de reprodução e variação do fator de condição (K) de Hypostomus affinis em duas drenagens costeiras do sudeste do Brasil, avaliando a influência da precipitação sobre esses aspectos biológicos. Métodos: Os peixes foram amostrados trimestralmente entre abril de 2008 e abril de 2010 em afluentes da bacia do Rio Doce (DRB) e do Rio Paraíba do Sul (PSRB). Os espécimes foram capturados com redes de emalhar. Os parâmetros de LWR foram avaliados por localização e sexo, através de um teste t. Usamos a frequência de espécimes maduros $\left(\mathrm{F}_{\mathrm{M}}\right)$ para avaliar o período de reproduçáo da espécie. Ambos os valores de $\mathrm{F}_{\mathrm{M}} \mathrm{e}$ K foram avaliados por uma equação sinusoidal. Resultados: Um total de 492 espécimes foi capturado, 
sendo 128 foram provenientes da DRB e 364 da PSRB. Em ambas as áreas, os espécimes apresentaram crescimento alométrico negativo. Coletamos espécimes maduros ao longo do período estudado em ambas as drenagens, sendo a maior frequência observada no início do período chuvoso. Encontramos uma correlaçáo positiva entre $\mathrm{F}_{\mathrm{M}}$ e a variação local da precipitação. $\mathrm{O}$ fator de condição $(\mathrm{K})$ foi menor na DRB e não apresentou tendência temporal. Por outro lado, foi observada uma variação de K para o indivíduo do PSRB, com um pico no período de transição seco-chuvoso. Porém, não foi possível correlacionar esse resultado com a variação da precipitação. Conclusóes: Os parâmetros de LWR de H. affinis foram consistentes com os dados já disponíveis na literatura. A precipitação pode influenciar o $\mathrm{F}_{\mathrm{M}}$, mas não os valores de $\mathrm{K}$. Nesse caso, aspectos biológicos como a reprodução e/ou alimentação podem estar influenciando uma variação discreta do fator de condição. A redução dos valores de $\mathrm{K}$ nos períodos chuvosos sugere um maior gasto energético para o processo reprodutivo. Em resumo, nossos resultados nos ajudam a entender o ciclo de vida de uma espécie de peixe em um ambiente altamente modificado, especialmente por barragens.

Palavras-chave: cascudo; relação peso-comprimento; biologia de peixes; reprodução; fator de condição.

\section{Introduction}

The Neotropical armored catfish family Loricariidae, commonly known as plecos, is one of the most species-rich fish families on Earth, with almost one thousand valid species (Fricke et al., 2021; Weber, 2003). Harboring about 150 species (Dias \& Zawadzki, 2018; van der Laan \& Fricke, 2021), the genus Hypostomus Lacepède, 1803 is the richness taxa within loricariids, and most of them are endemic to the Brazilian coastal drainages (Camelier \& Zanata, 2015). This genus usually fed on detritus (Power, 1984; Salvador Junior et al., 2009) and shows great adaptability to different habitats, from clear running water with rocky-bed to muddy water with soft bottoms (Garavello \& Garavello, 2004; Sales et al., 2016). For this reason, some Hypostomus species can withstand rivers damming, with a notorious adaptation of their life cycles to the reservoir environments (Duarte et al., 2011; Gomes et al., 2015).

The knowledge on the biological aspects of Hypostomus species is scarce, considering its diversity (Gomes et al., 2015). Until now, the existent studies regard few species, addressing: the breeding cycle (Galarça et al., 2014; Mazzoni \& Caramaschi, 1997), spawning behavior (Menezes \& Caramaschi, 1994), fecundity (Mazzoni \& Caramaschi, 1997; Takahashi et al., 2008), growth pattern (Salvador et al., 2018, 2017), and general reproductive tactics (Gomes et al., 2015; Sales et al., 2016). Although the shortfall in knowledge, the pleco Hypostomus affinis (Steindachner, 1877) is one of the most studied taxa of this genus regarding its biology (Duarte et al., 2011; Duarte \& Araújo, 2002; Mazzoni \& Caramaschi, 1997). This species is distributed along the south portion of the Brazilian coastal drainages, including the Paraíba do Sul and Doce River basins (Vieira, 2009; Vieira et al.,
2015; Vieira \& Rodrigues, 2010). It is considered a medium-size benthonic fish that feeds on detritus and reproducing primarily during the rainy season (Froese \& Pauly, 2021; Mazzoni \& Caramaschi, 1997). However, data on the reproductive traits of H. affinis is missing for the Doce River basin, or it is prevenient from decades ago for the Paraíba do Sul River basin (Mazzoni \& Caramaschi, 1997).

Studies addressing quantitative aspects of the population structure and reproductive biology, such as length-weight relationship (LWR), breeding period, and condition factor $(\mathrm{K})$, are essential tools to investigate the life cycle of freshwater fishes (Ferreira \& Súarez, 2015; Sales et al., 2016). LWR studies can be applied as a surrogate to weight when only the length is known and infer on reproductive fish biology when jointly assessed with other biological parameters (Freitas et al., 2016; Froese, 2006). The evaluation of a breeding period uses different characteristics; for instance, the gonadal maturation through a time series (Montag et al., 2011; Vazzoler, 1996). The condition factor index (K) is another commonly-used attribute in fish biology studies (Camara et al., 2011). This index represents the specimens' health, assuming that more body mass by a given length indicates a better physiological status of a specimen (Froese, 2006). A joint assessment of the seasonal variation of these parameters provides a sound basis for understanding fishes' ecology and their role in the aquatic environment (Vazzoler, 1996). This is especially true when biological data are associated and evaluate with abiotic factors, such as pluviosity. For instance, many fish species synchronize their reproduction with the rainy season, when conditions for the survival of juveniles are increased (Durham \& Wilde, 2008).

Given the above, this study aimed to assess biological aspects of the pleco Hypostomus affinis 
from two Brazilian Coastal drainages (Doce River basin and Paraíba do Sul River basin), as follow: (i) describe the species' growth type in these two basins, (ii) estimate the breeding season, and (iii) evaluate the influence of local rainfall rates in the reproduction and the species welfare. As reported in other studies, we assume that greater rainfall rates might be a relevant biological trigger for the reproductive activity of Hypostomus affinis.

\section{Material and Methods}

\subsection{Study area}

Samples were carried out in the Matipó river $\left(20^{\circ} 10^{\prime} 50^{\prime \prime} \mathrm{S} / 42^{\circ} 21^{\prime} 53^{\prime \prime} \mathrm{W}\right)$, a tributary from Doce river basin, and in the Glória $\left(21^{\circ} 02^{\prime} 25^{\prime \prime} \mathrm{S} / 42^{\circ} 19^{\prime} 45^{\prime \prime} \mathrm{W}\right)$ and Pomba rivers (21 $\left.20^{\circ} 49^{\prime \prime S} / 42^{\circ} 58^{\prime} 36^{\prime \prime} \mathrm{W}\right)$, both from Paraíba do Sul River basin, southeastern Brazil (Figure 1). These basins are included in the borderer aquatic ecoregions "Northeastern Mata Atlântica" and "Paraíba do Sul" (Abell et al., 2008). These areas are recognized by the high fish endemism rates (Bizerril, 1994; Camelier \& Zanata, 2015) and 65 hydroelectric dams (ANEEL, 2010).

In the Matipó River, we sampled five sites near the small hydroelectric power (SHP) Granada. This SHP has a reservoir with $0.33 \mathrm{~km}^{2}$ and a reduced flow stretch (RFS) of $2.3 \mathrm{~km}$ long and $20 \mathrm{~m} / \mathrm{km}$ slope. In the Pomba River, with four SHP built-in cascades, we established nine sampling sites along its course. The most upstream dam is the SHP Ponte, with a reservoir of $1.5 \mathrm{~km}^{2}$ and a RFS of one kilometer long and $45 \mathrm{~m} / \mathrm{km}$ slope, whereas the most downstream is the SHP Triunfo with a reservoir of $1.9 \mathrm{~km}^{2}$. Between them, there are the SHPs Palestina (reservoir of $0.6 \mathrm{~km}^{2}$ ) and Barra do Carrapato (reservoir of $0.3 \mathrm{~km}^{2}$ ). Finally, in Glória River (Figure 1), we sampled in ten samplings sites between the SHP Cachoeira Encoberta (reservoir of $0.2 \mathrm{~km}^{2}$, RFS of $0.7 \mathrm{~km}$, and $70 \mathrm{~m} / \mathrm{km}$ slope) and the SHP Glória (reservoir of one $\mathrm{km}^{2}$, RFS of one $\mathrm{km}$ of extension, and $45 \mathrm{~m} / \mathrm{km}$ slope).

Figure 1

\subsection{Sampling methods and biological data}

We collected specimens of $H$. affinis quarterly from April 2008 to April 2010 in the Paraíba do Sul River basin (hereafter as PSRB) and from July 2008 to April 2010 in the Doce River basin (hereafter as DRB). At each expedition, we expended 12 days on PSRB and five on DRB. We set gillnets of eight different mesh sizes $(30-120 \mathrm{~mm}$ mesh sizes) for fifteen hours per day (6:00 PM - 9:00 AM) under local fishermen's guidance. For all specimens, we measured the standard length (SL, centimeter, precision of $0.1 \mathrm{~cm}$ ) SL; to the nearest $0.1 \mathrm{~cm}$ ) and total mass (TM, gram, precision of $0.1 \mathrm{~g}$ ).

We visually determined the sex and maturation stages of each specimen through a macroscopic inspection of the gonads. Gonads of loricariids conform to the general pattern observed for teleosts: paired, longitudinally flattened, located in the dorso-posterior region, and joined each other at the caudal part, forming a common duct, terminating in a short duct, and finally opening at the urogenital papillae (Duarte et al., 2007; Suzuki et al., 2000). We sexed the individuals of Hypostomus affinis based on the morphology of gonads: testes are thin and filiform and ovaries fairly cylindrical, enlarged, and saculiform (Duarte et al., 2007). The gonadal maturation stages were adapted from the Núnez \& Duponchelle (2009): stage I (immature); stage II (maturing); stage III (mature); and stage IV (spawned for females and spent for males). These stages are defined according to the morphology, color, presence of oocytes (for females), and tissue appearance [see Núñez \& Duponchelle (2009) for detailed description].

Voucher specimens were fixed in 10\% formalin for $48 \mathrm{~h}$, transferred to $70 \%$ ethanol, and deposited in the museum of natural sciences of PUC Minas in Belo Horizonte (Minas Gerais, Brazil) under the codes MCNIP 1068 and MCNIP 1178. We used a collection license expedited by the Instituto Estadual de Florestas (IEF) under the numbers 003/08, 066/08, 062/09, and 064/09.

\subsection{Rainfall data}

We surveyed historical rainfall data in the database of the Instituto National de Meteorelogia (INMET, 2020) to evaluate its influence on the biological parameters of the $H$. affinis. Because no meteorological station was explicitly located within our studied area, we used the average rainfall data from the five nearest surrounding stations of our sampling sites, named: Barbacena (code 83689), Caparao (83639), Caratinga (83592), Coronel Pacheco (83037), and Viçosa (83642). The monthly rainfall averages obtained from these five stations are available in Table 1.

Table 1

\subsection{Data analysis}

We assessed the specimens for the length-weight relationship (LWR), breeding season, and condition 


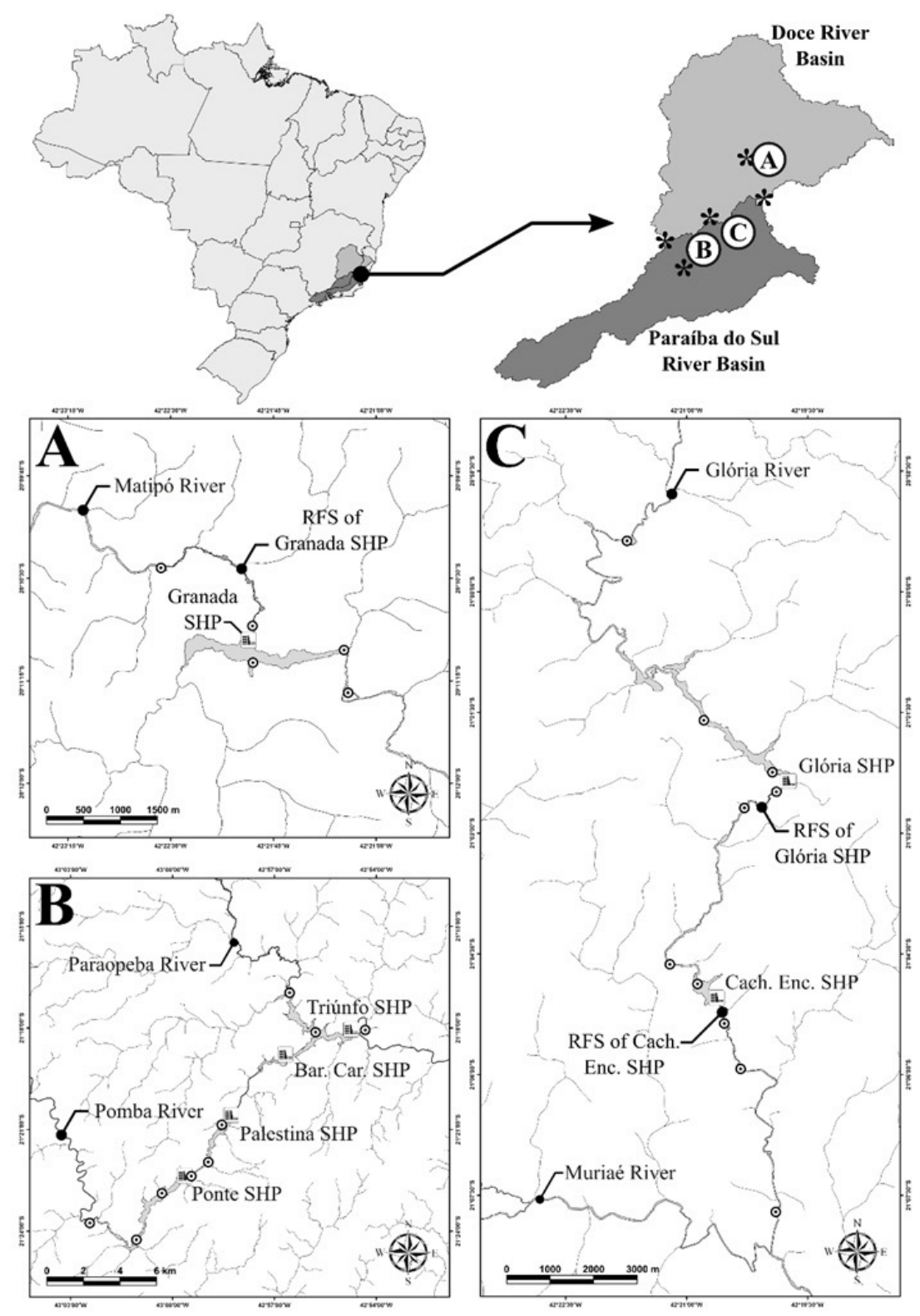

Figure 1. Map showing the location of the collection sites in the (A) Matipó River (Doce River basin) and (B) Glória and (C) Pomba Rivers (Paraíba do Sul River basin), southeastern Brazil. Circles with black spots represent the collection sites. SPH means small powerplant, and RFS means reduced flow stretch. * Location of the meteorological stations used to obtain the rainfall data.

factor $(K)$. The LWR followed the model first proposed by Järvi (1920) (see Froese, 2006), $T_{M}=a^{*} S_{L}^{b}$, and consider the total mass $\left(\mathrm{T}_{\mathrm{M}}\right)$, standard length $\left(S_{L}\right)$, coefficient of proportionality $(a)$, and the coefficient of allometry $(b)$. We interpreted the latter parameter as the fish growth type (Froese, 2006). First, to assess differences concerning growth patterns between the individuals from the two studied areas, we established a merged LWR for all specimens. Then, we compared the proportional residues of the $S_{L}$ ([observed-predicted $] /$ predicted) using a t-test (see
Fontoura \& Conter, 2008; Freitas et al., 2016). Once we identified morphological bias, the LWR was established separately for the specimens of each drainage. In the case of morphological segregation among the basins, we applied the routine mentioned above to evaluate differences for females and males. That is, if we also identified morphological bias between sexes, a separately LWR was established for males and females.

We evaluated the growth type ( $b$ values) by a t-test, comparing it with a hypothetical 
Table 1. Monthly rainfall average (April 2008 to April 2010) of five meteorological stations from southeast Brazil. Data obtained from the database of the Instituto National de Meteorelogia (INMET).

\begin{tabular}{|c|c|c|c|c|c|c|c|}
\hline \multirow{3}{*}{ Years } & \multirow{3}{*}{ Months } & \multicolumn{5}{|c|}{ Meteorological stations } & \multirow{3}{*}{ Averages } \\
\hline & & \multirow{2}{*}{$\begin{array}{c}\begin{array}{c}\text { Caratinga } \\
(83592)\end{array} \\
19^{\circ} 43^{\prime} 48^{\prime \prime} \mathrm{S} / \\
42^{\circ} 07^{\prime} 48^{\prime \prime} \mathrm{W}\end{array}$} & \multirow{2}{*}{$\begin{array}{c}\begin{array}{c}\text { Caparão } \\
(83639)\end{array} \\
20^{\circ} 30^{\prime} 36^{\prime \prime} \text { ' / } \\
41^{\circ} 54^{\prime} \mathrm{W}\end{array}$} & \multirow{2}{*}{$\begin{array}{c}\begin{array}{c}\text { Viçosa } \\
(83642)\end{array} \\
20^{\circ} 45^{\prime} 36 \text { "S/ } \\
42^{\circ} 51^{\prime} 36^{\prime \prime} \mathrm{W}\end{array}$} & \multirow{2}{*}{$\begin{array}{c}\begin{array}{c}\text { Coronel } \\
\text { Pacheco } \\
(83037)\end{array} \\
21^{\circ} 33^{\prime} \mathrm{S} / \\
43^{\circ} 15^{\prime} 36^{\prime \prime} \mathrm{W}\end{array}$} & \multirow{2}{*}{$\begin{array}{c}\begin{array}{c}\text { Barbacena } \\
(83689)\end{array} \\
21^{\circ} 15^{\prime} \mathrm{S} / \\
43^{\circ} 45^{\prime} 36^{\prime} \mathrm{W}\end{array}$} & \\
\hline & & & & & & & \\
\hline \multirow[t]{9}{*}{2008} & April & 91.8 & 123.1 & 62.8 & 135.0 & 141.0 & 110.7 \\
\hline & May & 7.3 & 13.4 & 7.2 & 0.0 & 1.6 & 5.9 \\
\hline & June & 19.5 & 9.4 & 12.7 & 20.5 & 10.1 & 14.4 \\
\hline & July & 2.0 & 7.4 & 0.2 & 0.0 & 1.0 & 2.1 \\
\hline & August & 21.4 & 8.0 & 15.4 & 6.0 & 12.4 & 12.6 \\
\hline & September & 30.7 & 101.8 & 147.4 & 62.7 & 88.2 & 86.2 \\
\hline & October & 32.9 & 38.4 & 41.4 & 175.3 & 109.0 & 79.4 \\
\hline & November & 253.5 & 376.9 & 224.8 & 3.0 & 232.4 & 218.1 \\
\hline & December & 260.6 & 497.7 & 605.7 & - & 466.0 & 457.5 \\
\hline \multirow[t]{12}{*}{2009} & January & 260.9 & 410.2 & 253.1 & 267.9 & 295.7 & 297.6 \\
\hline & February & 87.9 & 182.7 & 224.1 & 149.3 & 244.2 & 177.6 \\
\hline & March & 152.2 & 230.6 & 243.1 & 167.1 & 149.7 & 188.5 \\
\hline & April & 84.2 & 141.8 & 90.9 & 37.0 & 49.7 & 80.7 \\
\hline & My & 29.4 & 33.2 & 9.6 & - & 10.3 & 20.6 \\
\hline & June & 31.9 & 32.2 & 53.6 & - & 28.7 & 36.6 \\
\hline & July & 2.3 & 34.4 & 14.6 & - & 13.4 & 16.2 \\
\hline & August & 9.4 & 47.8 & 13.7 & - & 13.4 & 21.1 \\
\hline & September & 160.9 & 111.5 & 72.2 & - & 98.4 & 110.8 \\
\hline & October & 147.2 & 165.7 & 127.9 & - & 246.6 & 171.9 \\
\hline & November & 69.9 & 93.7 & 131.5 & - & 149.6 & 111.2 \\
\hline & December & 342.5 & 309.3 & 333.1 & - & 310.0 & 323.7 \\
\hline \multirow[t]{4}{*}{2010} & January & 85.1 & 78.2 & 117.7 & - & 273.6 & 138.7 \\
\hline & February & 50.0 & 56.0 & 37.8 & - & 74.0 & 54.5 \\
\hline & march & 249.4 & 251.1 & 192.5 & - & 277.0 & 242.5 \\
\hline & April & 63.0 & 58.3 & 18.3 & - & 66.8 & 51.6 \\
\hline
\end{tabular}

$b=3$ (isometric growth) when length and weight vary proportionately. The negative allometry $(b<3)$ occurs when the body length increases at a faster rate than weight, whereas positive allometry occurs when weight increases at a faster rate than length $(b>3)$ (Froese, 2006). We assessed the reproductive activity using the frequency of mature specimens $\left(F_{M}\right)$, which is given by the percentage of individuals in stage III of gonadal maturation of each field campaign. Although fish reproductive ecology is mostly assessed by the gonadosomatic index (GSI), our project had no contingency for a proper digital scale to measure gonad weights for the GSI calculation. However, our approach is considered reliable and was already applied as the primary method to assess fish breeding season in another study (Montag et al., 2011). Finally, we calculated the condition factor $(K)$ by the formula: $K=T_{M} / S_{L}{ }^{b}$, which considered the coefficient of allometry $(b)$ of the LWR.

For both analyses $\left(F_{M}\right.$ and $\left.K\right)$, we used a sinusoidal equation (SE) following Fontoura \& Agostinho (1996) (further applied by Freitas et al.,
2011; Montag et al., 2011), which describes a cyclic (seasonal trend) variation of a data. Using the sinusoidal equation instead of conventional analysis of variance is given by the increased sensitivity since we can evaluate a continuous process of a dataset instead of independent categories. Also, it allows a numerical description of the phenomena and the direct evaluation of time intervals between distinct cycles (Fontoura \& Agostinho, 1996).

The SE was based on the formula: $F_{M}$ or $K=M+A^{*} \cos (2 \pi / F r q *(t-f)), \quad M \quad$ where $M=$ the mean global value of the frequency of mature individuals $\left(F_{M}\right)$ or condition factor $(K)$, $A$ = amplitude of the $F_{M}$ or $K, F r q=$ units of time in which the events were measured (here, $F r q=4$; because our estimated time is "four" distinct hydrological period), $t$ (time) $=$ numerical scale of time [here, 1 = transitional rainy-dry period (which includes January, February, March - hereafter as "R-D"), 2 = dry period (April, May, June - "D"), 3 = transitional dry-rainy period (July, August, September - "D-R"), 4 = rainy period (October, 
November, December - "R")], and $f$ (phase) $=$ the difference between the baseline time (zero) and the time with the maximum mean of $F_{M}$ or $K$. That is, the phase signifies the time (hydrological periods) with more significant estimated values of $\mathrm{F}_{\mathrm{M}}$ or $\mathrm{K}$. We calculated a coefficient of determination $\left(\mathrm{R}^{2}\right)$ by the ratio of the sum of the squares of the residuals to the total sum of squares, and a p-values based on the F statistic (Zar, 2010). We estimated the sinusoidal equation's parameters by using the Solver routine of the Microsoft Office Excel ${ }^{\circledR} 2010$.

Lastly, in the case of significant $\mathrm{p}$ values of the sinusoidal equations, we correlated the $F_{M}$ and $K$ values against the local variation of rainfall by a Pearson correlation test (we checked the assumption criteria), using the software R (R Core Team, 2017). This analysis aimed to evaluate the correlation between the cyclic variation of these biological parameters against the seasonality of rainfall. We assessed all statistics with a 5\% significance level (Zar, 2010).

\section{Results}

We collected 492 specimens of $H$. affinis, of which 128 were from the Doce River basin (DRB) - 61 females and 67 males - and 364 from the Paraíba do Sul River basin (PSRB) - 175 females and 189 males. The LWR residues indicated a clear bias in the growth patterns concerning these two areas $(t=-14.255, \mathrm{p}<0.001)$, which elucidated the need to apply distinct LWR equations. That is, the growth pattern of $H$. affinis in the DBR and PSRB was different, and henceforward, the LWR and condition factor were analyzed separately for these basins.

Subsequently, the evaluation of LWR residues for the individuals from the DRB did not evidence differences in the growth pattern between males and females $(t=1.468, p=0.072)$, and we established a merged LWR equation through the formula $T_{M}=0.032 * S_{L}^{2.782}\left(\mathrm{R}^{2}=0.990\right)$. This indicates a negative allometric growth type for the population from the DRB $(t=7.786 ; p<0.001)$, which means that the specimens were increasing proportionately in length rather than weight. On the other hand, the LWR residues were biased between sexes for the set of specimens from the PSRB. Thus, it was necessary to establish an LWR equation for females $-T_{M}=0.076 * S_{L}^{2.753}\left(\mathrm{R}^{2}=0.955\right)-$ and for males $-T_{M}=0.063 * S_{L}^{2.697}\left(\mathrm{R}^{2}=0.979\right)-$ separately. Both equations indicated negative allometric growth either for females $(t=5.255, p<0.001)$ neither for males $(t=7.769, p<0.001)$. It also highlights that both sexes were increasing proportionately in length rather than weight. We summarized the LWR parameters in Table 2.

The frequencies of specimens in the mature stage of gonadal development $\left(F_{M}\right)$ showed a cyclic pattern for both studied areas (Figure 2). In the DRB, the $F_{M}$ varied from zero to 0.630 , with an average $F_{M}$ equal to $0.082(\mathrm{~F}=8.492, \mathrm{p}=0.029)$. In the PSRB, the $F_{M}$ varied from zero to 0.561 , with an average $F_{M}$ equal to $0.269(\mathrm{~F}=12.090, \mathrm{p}=0.015)$. The "phase" $(f)$ was equal to 3.977 for the DRB and 3.860 for the PSRB, which means that the peak of mature individuals occurred at the end of the transitional dry-rainy period for both areas (see material and methods). We summarized the results of the sinusoidal equation for the $F_{M}$ in Table 3 .

In addition, the linear regression model showed consistent relationship between the frequency of mature specimens $\left(F_{M}\right)$ and rainfall rates for the DRB ( $\left.y=0.002 x-0.043 ; R^{2}=0.509 ; \mathrm{p}=0.037\right)$ and PSRB $\left(y=0.001 x+0.083 ; R^{2}=0.407\right.$; $\mathrm{p}=0.048)$, which evidence the importance of pluviosity on the $H$. affinis reproduction.

Given the biased growth patterns between the studied areas, and also between sexes among the PSRB's specimens, we presented the condition factor $(K)$ as follows: 1$)$ separately for areas; 2) merged for sexes for the specimens from the DRB basin; and 3) separately for sexes for the individuals

Table 2. Parameters of the length-weight relationships of Hypostomus affinis from the Doce River basin (DRB) and the Paraíba do Sul River basin (PSRB), southeastern Brazil, collected between from April 2008 to April 2010. Sample size $(\mathrm{N})$; estimated a and b values with confidence limits $(95 \%)$, determination coefficient $\left(\mathrm{R}^{2}\right)$.

\begin{tabular}{|c|c|c|c|c|c|c|c|c|}
\hline \multirow{2}{*}{ Basins } & \multirow{2}{*}{ Sex } & \multirow{2}{*}{$\mathbf{N}$} & \multicolumn{2}{|c|}{ Estimated Parameters } & \multirow{2}{*}{$\mathbf{R}^{2}$} & \multirow{2}{*}{$t$ value } & \multirow{2}{*}{$p$ value } & \multirow{2}{*}{$\begin{array}{l}\text { Growth } \\
\text { pattern }\end{array}$} \\
\hline & & & a $(95 \% \mathrm{CL})$ & b (95\% CL) & & & & \\
\hline DRB & Merged & 128 & $\begin{array}{c}0.032 \\
(0.026-0.038)\end{array}$ & $\begin{array}{c}2.782 \\
(2.726-2.838)\end{array}$ & 0.989 & 7.786 & $<0.001$ & $\begin{array}{l}\text { Negative } \\
\text { allometry }\end{array}$ \\
\hline \multirow{2}{*}{ PSRB } & Females & 175 & $\begin{array}{c}0.076 \\
(0.053-0.099)\end{array}$ & $\begin{array}{c}2.753 \\
(2.660-2.846)\end{array}$ & 0.955 & 5.255 & $<0.001$ & $\begin{array}{l}\text { Negative } \\
\text { allometry }\end{array}$ \\
\hline & Males & 189 & $\begin{array}{c}0.063 \\
(0.047-0.080)\end{array}$ & $\begin{array}{c}2.697 \\
(2.619-2.774)\end{array}$ & 0.979 & 7.769 & $<0.001$ & $\begin{array}{l}\text { Negative } \\
\text { allometry }\end{array}$ \\
\hline
\end{tabular}




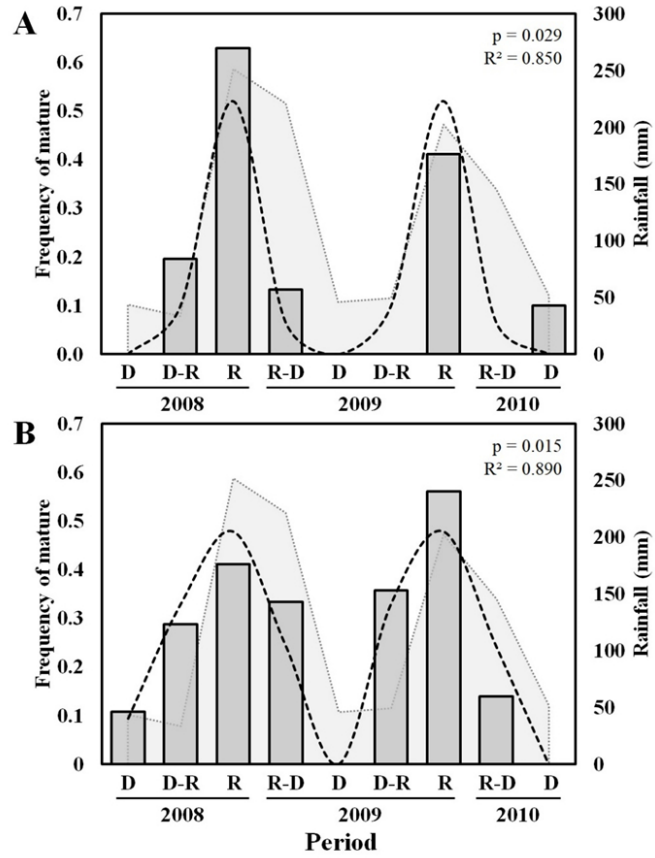

Figure 2. Frequency of mature specimens of Hypostomus affinis from the Doce River basin (A) and Paraíba do Sul River basin (B) through the hydrological periods $(\mathrm{D}=$ dry, $\mathrm{D}-\mathrm{R}=$ transitional dry-rainy period, $\mathrm{R}=$ rainy, and $\mathrm{R}-\mathrm{D}=$ transitional rainy-dry period). Statistics values presented are from the sinusoidal function (represented by the dotted curves). We show the rainfall variation in the grayness background. For visual comparison, we applied the same range of frequency in both graphics.

Table 3. Parameters of the sinusoidal equation for the relative frequencies of mature specimens of Hypostomus affinis from the Doce River basin (DRB) and the Paraíba do Sul River basin (PSRB), southeastern Brazil, collected between from April 2008 to April 2010.

\begin{tabular}{cccc}
\hline \multicolumn{2}{c}{ Parameters } & DRB & PSRB \\
\hline & Amplitude (A) & 0.439 & 0.197 \\
Frequency of & Mean (M) & 0.082 & 0.286 \\
mature (FM) & Phase (f) & 3.977 & 3.860 \\
& $R^{2}$ & 0.850 & 0.890 \\
& $p$ value & 0.029 & 0.015 \\
\hline
\end{tabular}

from the PSRB (Figure 3). The $K$ values from DRB's specimens varied from 0.021 to 0.036 , with an average equal to 0.029 , but did not bias toward a seasonal pattern $(\mathrm{F}=1.314, \mathrm{p}=0.447)$. In contrast, we evidenced a significant cyclic variation of $K$ values of females and males from the PSRB. For females, $K$ values varied from 0.032 to 0.060 , with an average equal to $0.044(\mathrm{~F}=50.690$, $\mathrm{p}=0.001)$. For males, $K$ values varied from 0.039 to

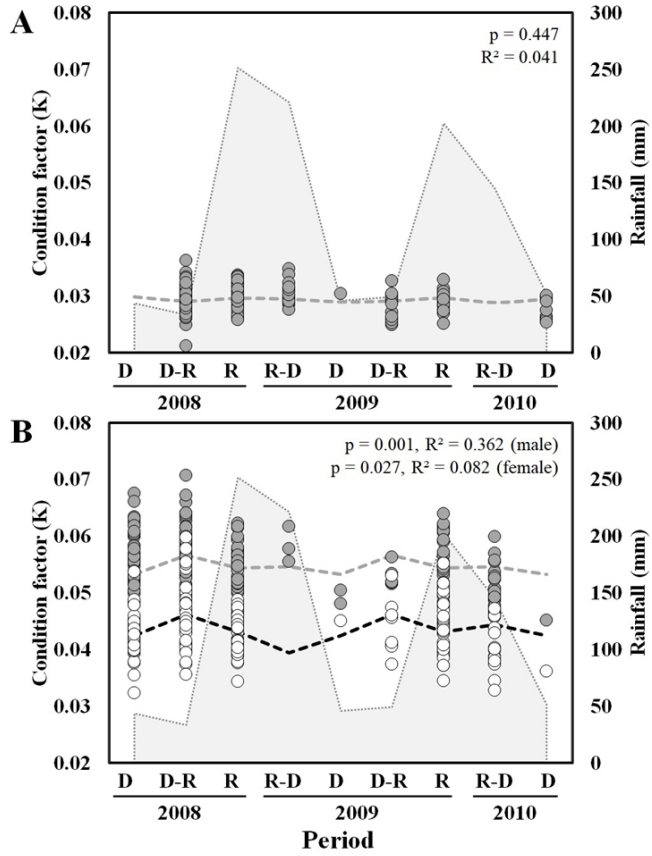

Figure 3. Variation of the condition factor of Hypostomus affinis from the Doce River basin (A) and Paraíba do Sul River basin (B) through the hydrological periods $(\mathrm{D}=$ dry, $\mathrm{D}-\mathrm{R}=$ transitional dry-rainy period, $\mathrm{R}=$ rainy, and $\mathrm{R}-\mathrm{D}=$ transitional rainy-dry period). We represented females by the light gray symbol and males by the dark gray. Statistics values presented are from the sinusoidal function (represented by the dotted curves). We show the rainfall variation in the grayness background. For visual comparison, we applied the same range of $\mathrm{K}$ values in both graphics.

0.071 , with an average equal to $0.055(\mathrm{~F}=7.962$, $\mathrm{p}=0.027)$. The "phase" ( $f$ parameter $)$ was equal to 3.067 for females and 2.997 for males, which represents the beginning of the transitional dryrainy period (D-R). We summarized the parameters of the sinusoidal equation evaluating the condition factor in Table 4.

Since we did not evidence a cyclic variation of K values for the DRB's specimens, we did not perform the linear regression model to assess the influence of the rainfall on the fish reproduction. On the other hand, the cyclic variation of $K$ values (for both sexes) for the population from the PSRB encouraged us to perform the linear regression between rainfall rates and $\mathrm{K}$ values. However, we did not notice significative relationship between these parameters for both sexes (females: $\mathrm{R}^{2}=0.188 ; \mathrm{p}=0.244 ;$ males: $\mathrm{R}^{2}=0.007 ;$ $\mathrm{p}=0.836$ ), which means that rainfall are not influencing the specimens' welfare. 
Table 4. Parameters of the sinusoidal equation for the condition factor of Hypostomus affinis from the Doce River basin (DRB) and the Paraíba do Sul River basin (PSRB), southeastern Brazil, collected between from April 2008 to April 2010.

\begin{tabular}{lccccc}
\hline \multirow{2}{*}{ Parameters } & DRB & & \multicolumn{2}{c}{ PSRB } \\
\cline { 3 - 3 } Condition factor (K) & Amplitude $(A)$ & Sex merged & & Female & Male \\
\hline & Mean $(M)$ & 0.001 & & 0.003 & 0.002 \\
& Phase $(f)$ & 0.029 & & 0.043 & 0.055 \\
& $R^{2}$ & 0.475 & & 3.067 & 2.997 \\
& $p$ value & 0.041 & & 0.362 & 0.082 \\
& & 0.447 & & 0.001 & 0.027 \\
\hline
\end{tabular}

\section{Discussion}

Our results showed a negative allometry growth type for $H$. affinis from the Doce River basin and Paraíba do Sul River basin. Although the LWR of H. affinis have been established for other basins, we showed it for the first time using specimens from the Doce River basin. We evidenced a prolonged breeding period, peaking in October for both sampled years (2008 and 2009), at the beginning of the rainy season. The cyclical variation in reproductive activity was positively correlated with the local rainfall variation. In our case, it means that we observed more mature individuals with the increase of rainfall. On the other hand, we found a cyclic variation of the condition factor only for specimens from the PSRB, peaking in August (2008 and 2009), representing the transitional dryrainy period. However, this variation of $K$ values was not related to the local rainfall quotas.

The allometric coefficients for $H$. affinis were coherent to other studies using the same pleco species (Albieri et al., 2014; Costa et al., 2014). An exception is shown by Mendonça et al. (2015), which recorded an isometric growth for H. affinis from Juturnaíba Reservoir, southeastern Brazil. The variation in the allometric coefficient in $H$. affinis is also in according to the pattern described to other Hypostomus species, which values ranging from 2.604 for Hypostomus margaritifer to 3.104 for Hypostomus velhochico, both from the São Francisco River basin (Nobile et al., 2015; Pessali et al., 2022; Salvador et al., 2018).

The growth pattern is a physiological response of each fish population according to the environmental features (e.g., rainfall, temperature) (Froese, 2006), which may explain the differences found in LWR of H. affinis between the studied basins herein. Given that each place has its biological characteristics (e.g., resource availability, inter and intraspecific relations), growth patterns can be changeable even within the same species (Fontoura et al., 2010;
Freitas et al., 2016) or between males and females of the same species (Freitas et al., 2016).

We observed mature specimens along the whole studied period for both drainages, with the highest frequency seen at the beginning of the rainy period (October 2008 and 2009). The reproduction in Hypostomus species seems to occur primarily in the rainy season (Mazzoni \& Caramaschi, 1997; Sales et al., 2016), despite some exceptions (e.g., (Medeiros \& Pompiani, 2009). A breeding peak in September to February was previously recorded for $H$. affinis from the Paraíba do Sul River (Mazzoni \& Caramaschi, 1995), corroborating our observations. Sympatric and congener species also showed a similar trend of the breeding season in the Paraíba do Sul River. For instance, the spawning period of Hypostomus luetkeni Lacepède 1803 and Hypostomus auroguttatus Kner, 1854 (now synonym of $H$. luetkeni) occurred throughout the year but also peaking in September-February (Mazzoni \& Caramaschi, 1997) and September-October (Gomes et al., 2015), respectively. Despite the overlapping in the reproductive period of both Hypostomus' species, they show distinct patterns of oocyte development (Duarte \& Araújo, 2002; Mazzoni \& Caramaschi, 1997) and segregation in habitat use, with $H$. affinis occurring from streams to reservoirs, and $H$. luetkeni being a species with more restricted distribution (Teixeira et al., 2005; Vieira et al., 2014). Additionally, the studies mentioned above (and our results) showed that the reproductive period of the Hypostomus species is influenced by environmental factors such as local rainfall periods and annual flood regimes. Those periods of the year coincide with the greater rainfalls and higher water levels in the Doce River basin and Paraíba do Sul River (Cruz et al., 2015; Marengo \& Alves, 2005). Concerning the condition factor, it is not possible to correlate the lower and evenness $K$ values for the specimens from DRB against the rainfall variation. However, we may link to other local environmental features, such as 
the physical characteristics of the habitat. Almost all individuals from DRB were collected in the reduced flow stretch (RFS) of the SHP Granada, which differs from other RFS. A noteworthy part of its extension shows a lower slope, with a flat and shallow river channel. This flow reduction creates a lentic-like environment where $H$. affinis shows high adaptability (Gomes et al., 2015). Although we did not perform a specific analysis to evaluate this scenario, a shallow and sunny aquatic environment might promote a higher availability of periphyton - the primary food source of $H$. affinis (Buck \& Sazima, 1995; Garavello \& Garavello, 2004). As a result, the abundance of $H$. affinis in this type of habitat may also increase, as reported by (Power, 1984) for grazers loricariid fishes. Again, although we did not formally test this relationship between environment and condition factor, it is feasible that a trade-off between food availability and fish abundance may promote lower (and uniform) $K$ values due to a possible interspecific competition (Grenouillet et al., 2002). In this case, biological aspects such as reproduction or even feeding (not evaluated here), maybe drive a discrete variation of the condition factor.

Regarding the cyclical variation of $K$ values of $H$. affinis from the PSRB, it was not possible to correlate it to the rainfall variation. That is, we argue that abiotic features would play a secondary role in the condition factor, and the reproductive process itself may be a crucial component to explain the $K$ variation. Despite higher $K$ values were recorded in the transitional dry-rainy period - the period before the reproductive intensity - the gonadal maturation or/and fat accumulation for breeding may be increasing the condition factor. The following reduction in $K$ values in the rainy season suggests a remarkable energetic cost for the reproductive process. This result is corroborated by Mazzoni \& Caramaschi (1995), which also found lower $K$ values among reproductive specimens of $H$. affinis in the Paraíba do Sul River basin and even for other siluriforms fishes (Freitas et al., 2011; Narahara et al., 2018).

In short, biological parameters of $H$. affinis in Brazilian coastal drainages seem to be influenced by environmental factors, such as rainfall rates. Despite our findings, the knowledge about the reproductive biology of this species and other loricariids from Brazilian coastal basins (Gomes et al., 2011; Zardo $\&$ Behr, 2015) is far from being flawless. There is still a striking challenge for biologists and ecologists to understand the effect of the anthropogenic environmental changes on the fishes' life cycle, particularly the river damming.

\section{Acknowledgments}

Coordenação de Aperfeiçoamento de Pessoal de Nível Superior (CAPES) and FAPEMIG (APQ00401-19) supported GNS. The authors are grateful to Dra. Renata Frederico for her assistance with the English review.

\section{References}

Abell, R., Thieme, M.L., Revenga, C., Bryer, M., Kottelat, M., Bogutskaya, N., Coad, B., Mandrak, N., Balderas, S.C., Bussing, W., Stiassny, M.L.J., Skelton, P., Allen, G.R., Unmack, P., Naseka, A., Ng, R., Sindorf, N., Robertson, J., Armijo, E., Higgins, J.V., Heibel, T.J., Wikramanayake, E., Olson, D., López, H.L., Reis, R.E., Lundberg, J.G., Sabaj Pérez, M.H., $\&$ Petry, P., 2008. Freshwater Ecoregions of the world: a new map of biogeographic units for freshwater biodiversity conservation. Bioscience 58(5), 403-414. http://dx.doi.org/10.1641/B580507.

Agência Nacional de Energia Elétrica - ANEEL, 2010. Sistema de Informaçôes Georreferenciadas do Setor Elétrico - SIGEL [online]. Brasília: ANEEL. Retrieved in 2019, April 02, from http://sigel.aneel. gov.br/sigel.html

Albieri, R.J.C.J., Costa, M.R., Santos, A.B.I., Albieri, R.J.C.J., \& Araújo, F.G., 2014. Weight-length relationships of 22 fish species from Paraíba do Sul River in Rio de Janeiro State, southeastern Brazil. J. Appl. Ichthyology 30(2), 431-433. http://dx.doi. org/10.1111/jai.12374.

Bizerril, C., 1994. Análise taxonômica e biogeográfica da ictiofauna de água doce do leste brasileiro. Acta Biol. Leopoldensia 16, 51-80.

Buck, S., \& Sazima, I., 1995. An assemblage of mailed cat fishes (Loricariidae) in southeastern Brazil: distribution, activity, and feeding. Ichthyol. Explor. Freshwat. 6, 325-332.

Camara, E.M., Caramaschi, E.P., \& Petry, A.C., 2011. Fator de condição: bases conceituais, aplicaçôes e perspectivas de uso em pesquisas ecológicas com peixes. Oecol. Aust. 15(2), 249-274. http://dx.doi. org/10.4257/oeco.2011.1502.05.

Camelier, P., \& Zanata, A.M., 2015. Biogeography of freshwater fishes from the Northeastern Mata Atlântica freshwater ecoregion: distribution, endemism, and area relationships. Neotrop. Ichthyol. 12(4), 683-698. http://dx.doi.org/10.1590/19820224-20130228.

Costa, M.R., Moreti, T., \& Araújo, F.G., 2014. Lengthweight relationships of 20 fish species in the Guandu River, Rio de Janeiro State, Southeastern Brazil. J. 
Appl. Ichthyology 30(1), 200-201. http://dx.doi. org/10.1111/jai.12296.

Cruz, F.M., Rocha, L.O., Cunha, D.M., Panquestor, E.K., \& Sena, I.B.D.C., 2015. Ondas de cheia no médio rio Doce: uma abordagem conceitual e estatística. In: VI Congresso Brasileiro de Gestáo Ambiental. Porto Alegre: IBEAS, 1-6.

Dias, A.C., \& Zawadzki, C.H., 2018. Identification key and pictures of the Hypostomus Lacépède, 1803 (Siluriformes, Loricariidae) from the rio Ivaí, upper rio Paraná basin. Check List 14(2), 393-414. http:// dx.doi.org/10.15560/14.2.393.

Duarte, S., \& Araújo, F.G., 2002. Fecundity of the Hypostomus affinis (Siluriformes, Loricariidae) in the Lajes Reservoir, Rio de Janeiro, Brazil. Rev. Biol. Trop. 50(1), 193-197. PMid:12298245.

Duarte, S., Araújo, F.G., \& Bazzoli, N., 2011. Reproductive plasticity of Hypostomus affinis (Siluriformes: Loricariidae) as a mechanism to adapt to a reservoir with poor habitat complexity. Zool. 28(5), 577-586. http://dx.doi.org/10.1590/S198446702011000500005 .

Duarte, S., Araújo, F.G., Sales, A., \& Bazzoli, N., 2007. Morphology of gonads, maturity and spawning season of Loricariichthys spixii (Siluriformes, Loricariidae) in a Subtropical Reservoir. Braz. Arch. Biol. Technol. 50(6), 1019-1032. http://dx.doi. org/10.1590/S1516-89132007000700013.

Durham, B.W., \& Wilde, G.R., 2008. Asynchronous and synchronous spawning by smalleye shiner Notropis buccula from the Brazos River, Texas. Ecol. Freshwat. Fish 17(4), 528-541. http://dx.doi. org/10.1111/j.1600-0633.2008.00303.x.

Ferreira, F.S., \& Súarez, Y.R., 2015. Estrutura populacional e aspectos reprodutivos de Corydoras aeneus (Siluriformes, Callichthyidae) em riachos da bacia do rio Ivinhema, Alto rio Paraná. Iheringia Ser. Zool. 105(4), 474-483. http://dx.doi.org/10.1590/1678476620151054474483.

Fontoura, N.F., \& Agostinho, A.A., 1996. Growth with seasonally varying temperatures: an expansion of the von Bertalanffy growth model. J. Fish Biol. 48(4), 569584. http://dx.doi.org/10.1111/j.1095-8649.1996. tb01453.x.

Fontoura, N.F., \& Conter, M.-R., 2008. Description of a new subspecies of the crayfish Parastacus brasiliensis (Von Martens, 1869) from Sao Francisco de Paula, RS, Brazil (Decapoda, Parastacidae). Zootaxa 1849(1), 28-34. http://dx.doi.org/10.11646/ zootaxa.1849.1.2.

Fontoura, N.F., Jesus, A.S., Larre, G.G., \& Porto, J.R., 2010. Can weight/length relationship predict size at first maturity? A case study with two species of Characidae. Neotrop. Ichthyol. 8(4), 835-840. http:// dx.doi.org/10.1590/S1679-62252010005000013.
Freitas, T.M.S., Almeida, V.H.C., Montag, L.F.A., \& Fontoura, N.F., 2016. Predicting size at first sexual maturity from length/weight relationship: a case study with an Amazonian catfish. Neotrop. Ichthyol. 14(4), e150152. http://dx.doi.org/10.1590/19820224-20150152.

Freitas, T.M.S., Almeida, V.H.C., Montag, L.F.A., Rocha, R.M., \& Fontoura, N.F., 2011. Seasonal changes in the gonadossomatic index, allometric condition factor and sex ratio of an auchenipterid catfish from eastern Amazonia. Neotrop. Ichthyol. 9(4), 839-847. http://dx.doi.org/10.1590/S167962252011005000044.

Fricke, R., Eschmeyer, W., \& Fong, J.D., 2021. Genera/species by family/subfamily in Eschmeyer's Catalog of Fishes [online]. San Franscico: Catalog of Fishes. Retrieved in 2021, February 20, from http://researcharchive. calacademy.org/research/ ichthyology/catalog/SpeciesByFamily.asp

Froese, R., \& Pauly, D., 2021. FishBase [online]. Stockholm: FishBase. Retrieved in 2021, February 18, from www.fishbase.org

Froese, R., 2006. Cube law, condition factor and weight-length relationships: history, meta-analysis and recommendations. J. Appl. Ichthyology 22(4), 241-253. http://dx.doi.org/10.1111/j.14390426.2006.00805.x.

Galarça, R.C.G., Müller, I.T.G., Spencer-Filho, H., Soares, R.E., Cunha, P., Gralha, T.S., Pessano, E.C., \& Querol, M.V.M., 2014. Período reprodutivo de fêmeas de Hypostomus commersoni Valenciennes, 1836, em uma barragem na bacia do rio Uruguai. Biotemas 27(2), 87-96. http://dx.doi.org/10.5007/2175$7925.2014 \mathrm{v} 27 \mathrm{n} 2 \mathrm{p} 87$.

Garavello, J.C., \& Garavello, J.P., 2004. Spatial distribution and interaction of four species of the catfish genus Hypostomus Lacépède with bottom of Rio São Francisco, Canindé do São Francisco, Sergipe, Brazil (Pisces, Loricariidae, Hypostominae). Braz. J. Biol. 64(3B), 591-598. http://dx.doi.org/10.1590/ S1519-69842004000400006. PMid:15619997.

Gomes, I.D., Araújo, F.G., Nascimento, A.A., \& Sales, A., 2015. Equilibrium reproductive strategy of the armored catfish Hypostomus auroguttatus (Siluriformes, Loricariidae) in a tropical river in Southeastern Brazil. Environ. Biol. Fishes 98(1), 249260. http://dx.doi.org/10.1007/s10641-014-0256-5.

Gomes, I.D., Araújo, F.G., Uehara, W., \& Sales, A., 2011. Reproductive biology of the armoured catfish Loricariichthys castaneus (Castelnau, 1855) in Lajes reservoir, southeastern Brazil. J. Appl. Ichthyology 27(6), 1322-1331. http://dx.doi.org/10.1111/ j.1439-0426.2011.01874.x.

Grenouillet, G., Pont, D., \& Seip, K.L., 2002. Abundance and species richness as a function of food resources and vegetation structure: juvenile fish assemblages 
in rivers. Ecography 25(6), 641-650. http://dx.doi. org/10.1034/j.1600-0587.2002.250601.x.

Intituto Nacional de Meteorologia - INMET, 2020. Banco de dados meteorológicos para ensino e pesquisa [online]. Brasília: INMET. Retrieved in 2020, April 10, from http://www.inmet.gov.br

Järvi, T.H., 1920. Die kleine Maräne (Coregonus albula L.) im Keitelesee, eine ö kologische und ökonomische Studie. Ann. Acad. Sci. Fenn. 1, 1-302.

Marengo, J.A., \& Alves, L.M., 2005. Tendências hidrológicas da bacia do rio Paraíba do Sul. Rev. Bras. Meteorol. 20, 215-226.

Mazzoni, R., \& Caramaschi, E.P., 1995. Size structure, sex ratio and onset of sexual maturity of two species of Hypostomus. J. Fish Biol. 47(5), 841-849. http:// dx.doi.org/10.1111/j.1095-8649.1995.tb06006.x.

Mazzoni, R., \& Caramaschi, E.P., 1997. Spawning season, ovarian development and fecundity of Hypostomus affinis (Osteichthyes, Loricariidae). Rev. Bras. Biol. 57, 455-462.

Medeiros, F.D., \& Pompiani, P.G., 2009. Aspectos da biologia populacional e reprodutiva de Hypostomus aff. cordobae e Hypostomus sp.1 (Loricariidae, Hypostominae), capturados à montante da cachoeira Aquarius, rio Correntes, MS. In: Anais do 7o ENIC. Dourados: Universidad Estadual do Mato Grosso do Sul, 1-15.

Mendonça, H.S., Silva-Camacho, D.S., Pinto, S.M., \& Araújo, F.G., 2015. Length-weight relationships of 14 fish species from a lowland tropical reservoir in southeastern Brazil. J. Appl. Ichthyology 31(5), 970972. http://dx.doi.org/10.1111/jai.12833.

Menezes, M.S., \& Caramaschi, E.P., 1994. Características reprodutivas de Hypostomus grupo $H$. punctatus no rio Ubatiba, Marica, RJ (Osteichthyes, Siluriformes). Rev. Bras. Biol. 54, 503-513.

Montag, L.F.A., Freitas, T.M.S., Raiol, R.D.O., \& Silva, M.V., 2011. Length-weight relationship and reproduction of the guppy Poecilia reticulata (Cyprinodontiformes: Poeciliidae) in urban drainage channels in the Brazilian city of Belém. Biota Neotrop. 11(3), 93-97. http://dx.doi.org/10.1590/ S1676-06032011000300007.

Narahara, M.Y., Godinho, H.M., Fenerichverani, N., \& Romagosa, E., 2018. Weight-length relationship and condition factor of Rhamdia hilarii Valenciennes, 1840 (Osteichthyes, Siluriformes, Pimelodidae). Bol. Inst. Pesca 12, 13-22.

Nobile, A.B., Brambilla, E.M., Lima, F.P., Freitas-Souza, D., Bayona-Perez, I.L., \& Carvalho, E.D., 2015. Length-weight relationship of 37 fish species from the Taquari River (Paranapanema Basin, Brazil). J. Appl. Ichthyology 31(3), 580-582. http://dx.doi. org/10.1111/jai.12761.

Núñez, J., \& Duponchelle, F., 2009. Towards a universal scale to assess sexual maturation and related life history traits in oviparous teleost fishes. Fish Physiol. Biochem. 35(1), 167-180. http://dx.doi. org/10.1007/s10695-008-9241-2. PMid:18668334.

Pessali, T.C., Salvador, G.N., Alves, C.B.M., Drager, D.H.C., Zawadzki, C.H., Prata, E.G., Vieira, F., Santos, G.B., Rosa, G.R., Penido, I.S., Gomes, J.P.C., Brito, M.F.G., Pompeu, P.S., Leitão, R.P., Santos, S.A., Barroso, T.A., Ribeiro, T.C., Sousa, T.J., DalaCorte, R.B., \& Freitas, T.M.S., 2022. Length-weight relationships of 78 fish species from Sáo Francisco River basin, Brazil. J. Appl. Ichthyology. (In press)

Power, M.E., 1984. Grazing responses of tropical freshwater fishes to different scales of variation in their food. Environ. Biol. Fishes 9, 25-38. https:// doi.org/10.1007/978-94-015-7682-6_2.

R Core Team, 2017. R: A language and environment for statistical computing [online]. Viena: R Foundation for Statistical Computing. Retrieved in 2019, May 02, from http://www.R-project.org

Sales, C.F., Domingos, F.F.T., Brighenti, L.S., Ribeiro, R.I.M.A., Santos, H.B., \& Thomé, R.G., 2016. Biological variables of Hypostomus francisci (Siluriformes: Loricariidae) from Itapecerica River, Minas Gerais State, Brazil. An. Acad. Bras. Cienc. 88(3 Suppl.), 1603-1614. http:// dx.doi.org/10.1590/0001-3765201620150513. PMid:27411068.

Salvador Júnior, L.F., Salvador, G.N., \& Santos, G.B., 2009. Morphology of the digestive tract and feeding habits of Loricaria lentiginosa Isbrücker, 1979 in a Brazilian reservoir. Acta Zool. 90(2), 101-109. http:// dx.doi.org/10.1111/j.1463-6395.2008.00336.x.

Salvador, G.N., Frederico, R.G., Pessali, T.C., Vieira, F., $\&$ Freitas, T.M.S., 2018. Length-weight relationship of 21 fish species from Rio Doce River basin, Minas Gerais, Brazil. J. Appl. Ichthyology 34(5), 11981201. http://dx.doi.org/10.1111/jai.13734.

Salvador, G.N., Pessali, T.C., Andrade, A.F.A., \& Freitas, T.M.S., 2017. Length-weight relationships of seven fish species from Jequitinhonha River basin, southeastern Brazil. J. Appl. Ichthyology 33(6), 1281-1283. http:// dx.doi.org/10.1111/jai.13502.

Suzuki, H.I., Agostinho, A.A., \& Winemiller, K.O., 2000. Relationship between oocyte morphology and reproductive strategy in loricariid catfishes of the Parana River, Brazil. J. Fish Biol. 57, 791807. https://doi.org/10.1111/j.1095-8649.2000. tb00275.x.

Takahashi, E.L.H., Gointein, R., \& Nakaghi, L.S.O., 2008. Maturidade do ovário no cascudo Hypostomus strigaticeps (Siluriformes, Loriicaridae). Acta Sci. Biol. Sci. 30(1), 107-112. http://dx.doi.org/10.4025/ actascibiolsci.v30i1.1474.

Teixeira, T.P., Pinto, B.C.T., Terra, B.F., Estiliano, E.O., Gracia, D., \& Araújo, F.G., 2005. Diversidade das assembléias de peixes nas quatro unidades 
geográficas do rio Paraíba do Sul. Iheringia Ser. Zool. 95(4), 347-357. http://dx.doi.org/10.1590/S007347212005000400002 .

van der Laan, R., \& Fricke, R., 2021. Eschmeyer's Catalog of Fishes [online]. San Franscico: Catalog of Fishes. Retrieved in 2021, February 20, from https://researcharchive.calacademy.org/research/ ichthyology/catalog/fishcatget.asp?spid=13936.

Vazzoler, A., 1996. Biologia da reprodução de peixes teleósteos: teoria e prática. Maringá: EDUEM/SBI/ $\mathrm{CNPq} /$ Nupelia.

Vieira, F., \& Rodrigues, R.R., 2010. A fauna de peixes dos afluentes do rio Paraíba do Sul no estado de Minas Gerais. MG-Biota 3, 5-23.

Vieira, F., 2009. Distribuição, impactos ambientais e conservação da fauna de peixes da bacia do rio Doce. MG-Biota 2, 5-22.

Vieira, F., Gasparini, J.L., \& Macieira, R.M., 2014. Guia ilustrado dos peixes da bacia do rio Benevente - ES. Vitória: GSA.
Vieira, F., Gomes, J.P.C.G., Maia, B.P., \& Silva, L.G.M., 2015. Peixes do Quadrilátero Ferrífero: guia de identificação. Belo Horizonte: Fundação Biodiversitas.

Weber, C., 2003. Subfamily Hypostominae (Armored catfishes). In: Reis, R.E., Kullander, S.O. \& Ferraris Junior, C.J., eds. Checklist of the freshwater fishes of South and Central America. Porto Alegre: EDIPUCRS, 351-372.

Zar, J.H., 2010. Biostatistical analysis (5th ed.). New Jersey: Prentice Hall.

Zardo, E.L., \& Behr, E.R., 2015. Population structure and reproductive biology of Loricariichthys melanocheilus Reis \& Pereira, 2000 (Siluriformes: Loricariidae) in the rio Ibicuí, Brazil. Neotrop. Ichthyol. 13(2), 371-382. http://dx.doi.org/10.1590/1982-0224-20140052.

Received: 27 February 2021 Accepted: 06 December 2021

Associate Editor: Gustavo Henrique Gonzaga da Silva 